\title{
Small Intestine Cancer pNX TNM Finding v7
}

National Cancer Institute

\section{Source}

National Cancer Institute. Small Intestine Cancer pNX TNM Finding v7. NCI Thesaurus.

Code $C 89875$.

Small intestine cancer in which regional lymph nodes cannot be assessed. (from AJCC 7th Ed.) 